\title{
Reset Osmostat in an Infant with Failure to Thrive
}

Mohammad Ilyas* and Asad Tolaymat

Pediatric Nephrology, University of Florida/Jacksonville, Florida, USA

*Corresponding author: Mohammad Ilyas, Clinical Assistant Professor, Pediatric Nephrology, University of Florida/Jacksonville, 841 Prudential Drives Suite \# 1900, Jacksonville, Florida 32207, USA, Tel: 904633 0920; Fax: 904633 0921; E-mail: mohammad.ilyas@jax.ufl.edu

Rec date: Mar 27, 2014, Acc date: May 10, 2014, Pub date: May 16, 2014

Copyright: (c) 2014 llyas M, et al. This is an open-access article distributed under the terms of the Creative Commons Attribution License, which permits unrestricted use, distribution, and reproduction in any medium, provided the original author and source are credited.

\begin{abstract}
We are reporting an infant who was presented to our institution exhibiting a failure to thrive and hyponatremia. An extensive renal evaluation revealed resistive hyponatremia with normal renal glomerular and tubular function. Patient remained hyponatremic even after fluid restriction, salt loading and Fludrocortisone (Florinef) administration. Water deprivation and water loading tests were suggestive of "hyponatremia of reset osmostat". The infant had no congenital midline defect.
\end{abstract}

Keywords: Resistive hyponatremia; Reset osmostat; Failure to thrive

\section{Introduction}

Hyponatremia is an important and common electrolyte abnormality usually seen in pediatric inpatients as an isolated finding or as a complication of other medical illnesses. Osmostat is the regulatory center at the hypothalamus that controls the osmolality of the extracellular fluid. Serum sodium concentration and serum osmolarity normally are maintained under precise control via hypothalamic osmo-receptors involving stimulation of thirst, secretion of antidiuretic hormone (ADH), and renal handling of filtered sodium [1]. Hyponatremia is frequently attributed to the syndrome of inappropriate antidiuretic hormone (SIADH). In this condition, despite a low serum sodium and mild volume expansion, the persistent presence of $\mathrm{ADH}$ results in concentrated urine (i.e. urine osmolality is higher than plasma osmolality) with a relatively large quantity of sodium. In chronic hyponatremia of reset osmostat, salt and water intake is appropriate but the osmotic threshold for the production and inhibition of $\mathrm{ADH}$ occurs at lower level [2]. We are reporting an infant who presented with failure to thrive and euvolemic hyponatremia due to a low set osmostat.

\section{Case Report}

A six-month-old white male was the product of a full-term uneventful pregnancy, no polyhydramnios, oligohydramnios or congenital defects. He was delivered vaginally with a birth weight of 3.0 kilograms. He was first admitted to a local hospital at two weeks of age with jaundice and low serum sodium (Na $122 \mathrm{mEq} / \mathrm{L})$. He had no gastrointestinal symptoms of diarrhea or vomiting. He had no underlying cardiovascular, respiratory and neurological symptoms. He had poor weight gain despite receiving adequate calories of about 110 $\mathrm{Cal} / \mathrm{kg} /$ day. At the age of six weeks, he was readmitted with the concern of failure to thrive. Otherwise, he had no medical symptoms and normal oral intake. His physical examination revealed awake, alert and active, but both height and weight were below 5th percentile for his age. His vital signs were normal; he was normotensive and had no tachypnea, tachycardia or fever. He was normocephalic with anterior fontanel open and flat, no facial dysmorphic features but appears small for age. He has no physical evidence of edema or dehydration. His ears, nose, throat, respiratory, cardiovascular, gastrointestinal, neurological, genitourinary and musculoskeletal exams were all within the normal limits. His developmental milestones were appropriate for his age. Although his formula was increased to a 24 -calorie (i.e. 120 $\mathrm{Cal} / \mathrm{kg} /$ day), he still failed to gain weight. At the age of six months, his weight was 5.2 kilogram (i.e. below 5 th percentile) and height was 58 centimeters (i.e. below 5 th percentile). His detailed laboratories studies are shown in Table 1. His renal ultrasound and brain MRI were both normal.

\begin{tabular}{|l|l|l|}
\hline Serum & Patients Range & Normal Values \\
\hline Sodium & $122-130 \mathrm{mEq} / \mathrm{L}$ & $135-151 \mathrm{mEq} / \mathrm{L}$ \\
\hline Potassium & $4.0-5.8 \mathrm{mEq} / \mathrm{L}$ & $3.2-5.9 \mathrm{mEq} / \mathrm{L}$ \\
\hline Chloride & $93-99 \mathrm{mEq} / \mathrm{L}$ & $98-110 \mathrm{mEq} / \mathrm{L}$ \\
\hline HCO3 & $18-23 \mathrm{mEq} / \mathrm{L}$ & $20-27 \mathrm{mEq} / \mathrm{L}$ \\
\hline BUN & $10-20 \mathrm{mg} / \mathrm{dl}$ & $5-18 \mathrm{mg} / \mathrm{dl}$ \\
\hline Creatinine & $0.2-0.3 \mathrm{mg} / \mathrm{dl}$ & $0.2-0.4 \mathrm{mg} / \mathrm{dl}$ \\
\hline Glucose & $50-92 \mathrm{mg} / \mathrm{dl}$ & $50-99 \mathrm{mg} / \mathrm{dl}$ \\
\hline Calcium & $10.5 \mathrm{mg} / \mathrm{dl}$ & $8.9-10.8 \mathrm{mg} / \mathrm{dl}$ \\
\hline PO4 & $5.1 \mathrm{mg} / \mathrm{dl}$ & $4.5-6.4 \mathrm{mg} / \mathrm{dl}$ \\
\hline Osmolality & $272-277 \mathrm{mOm} / \mathrm{Kg}$ & $275-295 \mathrm{mOm} / \mathrm{Kg}$ \\
\hline $\begin{array}{l}\text { Alkaline } \\
\text { Phosphatase }\end{array}$ & $191 \mathrm{IU} / \mathrm{L}$ & $20-150 \mathrm{IU} / \mathrm{L}$ \\
\hline Uric Acid & $4.6 \mathrm{mg} / \mathrm{dl}$ & $2.5-5.5 \mathrm{mg} / \mathrm{dl}$ \\
\hline TSH & $4.1 \mathrm{ng} / \mathrm{dl}$ & $3-18 \mathrm{ng} / \mathrm{dl}$ \\
\hline T4 & $1.4 \mathrm{ng} / \mathrm{dl}$ & $0.8-2.4 \mathrm{ng} / \mathrm{dl}$ \\
\hline ACTH & $<10 \mathrm{pg} / \mathrm{ml}$ & $25-100 \mathrm{pg} / \mathrm{ml}$ \\
\hline Renin & $3.26 \mathrm{ng} / \mathrm{ml} / \mathrm{hr}$ & $2.9-24 \mathrm{ng} / \mathrm{ml} / \mathrm{hr}$ \\
\hline
\end{tabular}


Page 2 of 4

Aldosterone $33.9 \mathrm{ng} / \mathrm{dl}$ $1-160 \mathrm{ng} / \mathrm{d}$

Table 1: The pertinent laboratories values

\section{Special studies for workup of hyponatremia}

To clarify the mechanism responsible for hyponatremia, we performed several physiological studies including a water deprivation, water loading, salt loading and Fludrocortisone challenge tests. The study results are discussed below and summarized in Table 2 .

\begin{tabular}{|l|l|l|l|l|l|l|l|l|}
\hline & \multicolumn{2}{|l|}{$\begin{array}{l}\text { Water } \\
\text { deprivation }\end{array}$} & \multicolumn{2}{l|}{$\begin{array}{l}\text { Water } \\
\text { loading }\end{array}$} & \multicolumn{2}{l|}{$\begin{array}{l}\text { Salt } \\
\text { loading }\end{array}$} & \multicolumn{2}{l|}{$\begin{array}{l}\text { Florinef } \\
\text { challenge }\end{array}$} \\
\cline { 2 - 9 } & $\begin{array}{l}\text { Befor } \\
\text { e After }\end{array}$ & $\begin{array}{l}\text { Befor } \\
\text { e }\end{array}$ & After & $\begin{array}{l}\text { Befor } \\
\text { e }\end{array}$ & $\begin{array}{l}\text { Afte } \\
\text { r }\end{array}$ & Before & After \\
\hline $\begin{array}{l}\text { Serum } \\
\text { (mEq/L) }\end{array}$ & 125 & 129 & 127 & 128 & 125 & 133 & 124 & 127 \\
\hline $\begin{array}{l}\text { Serum- } \\
\text { Osmolality } \\
\text { (mEq/L) }\end{array}$ & 269 & 277 & 263 & 270 & 272 & 276 & 268 & 269 \\
\hline $\begin{array}{l}\text { Urine flow } \\
\text { rate (ml/min) }\end{array}$ & 0.44 & 0.01 & 0.2 & 0.95 & 0.2 & 0.04 & - & \\
\hline $\begin{array}{l}\text { Urine } \\
\text { osmolality } \\
\text { (mOs/kg,) }\end{array}$ & 128 & 576 & 283 & 59 & 323 & 586 & 223 & 382 \\
\hline Fe Na (\%) & 0.52 & 0.13 & 0.5 & 0.2 & 0.25 & 0.65 & 0.67 & 0.24 \\
\hline $\begin{array}{l}\text { Water } \\
\text { clearance (mI/ } \\
\text { min) }\end{array}$ & -0.57 & -1.05 & -0.13 & 0.74 & 0.78 & 0.13 & - & \\
\hline
\end{tabular}

Table 2: The results of different tests are summarized in this table

\section{Water deprivation test}

A nine hour water deprivation resulted in a $3.6 \%$ weight loss. The urine flow declined and the free water clearance diminished. The patient was able to concentrate urine to a level of 576 milliosmoles. His serum sodium remained at $129 \mathrm{mEq} / \mathrm{L}$.

\section{Water loading test}

The patient was given a standard water-loading test of D5W 20 $\mathrm{ml} / \mathrm{kg}$ IV over 30 minutes. The patient excreted the infused water over 4 hours. He was able to dilute the urine to 58 milliosmoles per kilogram although his serum sodium persisted at $128 \mathrm{mEq} / \mathrm{L}$.

\section{Salt loading test}

Intravenous $3 \%$ saline $(0.513 \mathrm{mEq} \mathrm{Na} / \mathrm{ml})$ was infused at a rate of $0.2 \mathrm{ml} / \mathrm{kg} / \mathrm{min}$ for 30 minutes $(3 \mathrm{mEq} / \mathrm{kg})$. A transient increase in serum sodium from $125 \mathrm{mEq} / \mathrm{L}$ to $133 \mathrm{mEq} / \mathrm{L}$ was observed following the infusion. Water clearance and urine flow decreased, and the urine osmolality and fractional excretion of sodium increased.

\section{Fludrocortisone challenge test}

Fludrocortisone $50 \mathrm{mcg}$ was given orally. It had a minimal effect on serum sodium and serum osmolality level. Fractional excretion of sodium decreased from a baseline of $0.67 \%$ to $0.24 \%$.

\section{Genetic testing}

Single gene test for AVPR2 DNA sequence testing was performed at Athena Diagnostics, which showed a sequence of unknown significance for Nephrogenic Diabetes Insipidus (NDI). The sequence variant profile found does not allow any conclusion as to whether the patient is affected with NDI; because significance of one or more variants in AVPR2 for NDI remains unknown.

\section{Discussion}

Sodium is a predominant extracellular cation and cannot freely cross the cell membrane. Its homeostasis is vital to the normal physiologic function of cells. Hyponatremia is defined as a serum sodium level of less than $135 \mathrm{mEq} / \mathrm{L}$ and is considered severe when the serum sodium level is below $125 \mathrm{mEq} / \mathrm{L}$. Hyponatremia is a known cause of growth failure in infancy as well as beyond neonatal period probably into adulthood. Sodium $(\mathrm{Na})$ is an important growth factor, stimulating cell proliferation and protein synthesis and increasing cell mass. Sodium chloride $(\mathrm{NaCl})$ deprivation inhibits growth, as reflected by reduced body and brain weight, length, muscle and brain protein, RNA content and brain lipid content compared with controls. This is not due to deficiency of other nutrients since control and experimental diets were identical except for $\mathrm{NaCl}$ content [3]. This relationship between total body sodium depletion and failure to thrive may extend well beyond the neonatal period and possibly into adulthood [4].

Hyponatremia has traditionally been attributed to the syndrome of inappropriate secretion of antidiuretic hormone (SIADH) or cerebral salt wasting syndrome [5]. The syndrome of inappropriate antidiuretic hormone secretion (SIADH) should be suspected in any patient with hyponatremia, hypo-osmolality, and a urine osmolality above 100 mosmol $/ \mathrm{kg}$, a urine sodium concentration that is usually above 40 $\mathrm{meq} / \mathrm{L}$, with normal potassium, normal acid-base balance, and frequently low plasma uric acid concentration [6]. Feldman et al. described a SIADH-like clinical picture, which he termed Nephrogenic Syndrome of SIADH [7]. This was attributed to a mutation of the V2R gene causing constitutive activation of the receptors. This prompted us to obtain AVPR2 DNA sequence testing. The result showed an abnormal sequence of unknown clinical significance. Our patient however, does not meet the criteria for the diagnosis of SIADH. He was able to excrete free water and dilute the urine at osmolality of 58 mosmol/kg with urine sodium excretion of less than $10 \mathrm{mEq} / \mathrm{L}$.

Reset osmostat is a rare condition in which hyponatremia occurs because of a "low set of osmostat." In this condition, the renal concentrating and diluting capacities are intact. However, the regulation of arginine vasopressin $(\mathrm{ADH})$, which maintains serum tonicity, occurs at a lower osmolality threshold [8].

Patients with reset osmostat syndrome exhibit following characteristic features of the disease:

They maintain euvolemic hyponatremia with normal renal, adrenal and thyroid function.

They have no evidence of cardiac, hepatic and central nervous systems disease.

They have normal water excretion (i.e. excretion of more than $80 \%$ within 4 hours) to a standard water load (i.e. 10 to $15 \mathrm{~mL} \mathrm{D} 5 \mathrm{~W} / \mathrm{kg}$ given orally or intravenously). 
Page 3 of 4

They have intact urine diluting ability. They achieve essentially normal urine dilution after a water-loading test. (i.e. Urine osmolality less than $100 \mathrm{mOsm} / \mathrm{kg}$ )

They retain the ability to concentrate urine once the serum osmolality level is above the reset level [9].

These features constitute the diagnostic criteria of reset osmostat and our patient fulfilled all these criteria. Patients with reset osmostat who were previously described in the literature had an underlying syndrome such as a severe pulmonary [10], neurologic [11], malignancy [12] and infection [13]. Additionally, reset osmostat was reported in patients with spinal cord injury, marked psychiatric problems, alcoholism, cerebral palsy, and cleft lip or palate [14-16]. Rest osmostat in an infant with merely failure to thrive have seldom been described in literature. All reported neonates with reset osmostat however, have an underlying midline defect [17,18]. Previously reported children with reset osmostat are summarized in Table 3. Our patient has none of the above congenital defects.

\begin{tabular}{|c|c|c|c|c|c|c|}
\hline Authors & $\begin{array}{l}\text { Gende } \\
r \\
\text { Age at } \\
\text { Diagn } \\
\text { osis }\end{array}$ & $\begin{array}{l}\text { Physica } \\
\text { I } \\
\text { Abnor } \\
\text { malities }\end{array}$ & $\begin{array}{l}\text { Serum- } \\
\mathrm{Na}\end{array}$ & $\begin{array}{l}\text { Diagnosti } \\
\text { c } \\
\text { Studies }\end{array}$ & $\begin{array}{l}\text { Treatme } \\
\text { nt }\end{array}$ & Genetics \\
\hline $\begin{array}{l}\text { Banister P } \\
{[6]}\end{array}$ & $\begin{array}{l}\text { Male } \\
6 \\
\text { years }\end{array}$ & $\begin{array}{l}\text { Develop } \\
\text { mental } \\
\text { delay, } \\
\text { agenesi } \\
\text { s of } \\
\text { corpus } \\
\text { callosu } \\
\text { m, } \\
\text { hypothal } \\
\text { amic } \\
\text { cyst, }\end{array}$ & $126-128$ & $\begin{array}{l}\text { WLT } \\
\text { WDT } \\
\text { Na LT }\end{array}$ & $\begin{array}{l}\mathrm{Na} \\
\text { suppleme } \\
\mathrm{nt}\end{array}$ & NA \\
\hline $\begin{array}{l}\text { Farahnak } \\
\mathrm{K} \\
\text { Assadi [12] }\end{array}$ & $\begin{array}{l}\text { Male } \\
8 \\
\text { month } \\
\mathrm{s}\end{array}$ & $\begin{array}{l}\text { Cleft } \\
\text { palate } \\
\text { and lips }\end{array}$ & $125-130$ & $\begin{array}{l}\text { WLT } \\
\text { WDT } \\
\text { Na LT }\end{array}$ & $\begin{array}{l}\mathrm{Na} \\
\text { suppleme } \\
\mathrm{nt}\end{array}$ & NA \\
\hline $\begin{array}{l}\text { Thiagaraja } \\
\text { n R et } \\
\text { al. [13] }\end{array}$ & $\begin{array}{l}\text { Femal } \\
\text { e } \\
\text { Newbo } \\
\text { rn }\end{array}$ & $\begin{array}{l}\text { Midline } \\
\text { cleft lip } \\
\text { and } \\
\text { palate }\end{array}$ & $124-130$ & $\begin{array}{l}\text { WDT } \\
\text { Na LT }\end{array}$ & $\begin{array}{l}\text { Florinef } \\
\mathrm{Na} \\
\text { suppleme } \\
\text { nt }\end{array}$ & NA \\
\hline $\begin{array}{l}\text { Gupta } P \text { et } \\
\text { al. [14] }\end{array}$ & $\begin{array}{l}\text { Femal } \\
\text { e } \\
\text { Newbo } \\
\text { rn }\end{array}$ & $\begin{array}{l}\text { Midline } \\
\text { defects }\end{array}$ & $129-133$ & Na LT & $\begin{array}{l}\text { Glucocort } \\
\text { icoids }\end{array}$ & $\begin{array}{l}\text { Karyotyp } \\
\text { e X,-X, } \\
+\operatorname{der}(X) \\
t(X ; 13) \\
\text { (p22.1;q2 } \\
2)\end{array}$ \\
\hline $\begin{array}{l}\text { llyas et al. } \\
\text { (current } \\
\text { case) }\end{array}$ & $\begin{array}{l}\text { Male } \\
2 \\
\text { weeks }\end{array}$ & $\begin{array}{l}\text { Failure } \\
\text { to thrive }\end{array}$ & $122-133$ & $\begin{array}{l}\text { WLT } \\
\text { WDT } \\
\text { Na LT }\end{array}$ & $\begin{array}{l}\text { Florinef } \\
\mathrm{Na} \\
\text { suppleme } \\
\text { nt }\end{array}$ & $\begin{array}{l}\text { AVPR2 } \\
\text { Sequenc } \\
\text { e of } \\
\text { unknown } \\
\text { Significan } \\
\text { ce for } \\
\text { NDI. }\end{array}$ \\
\hline
\end{tabular}

Table 3: The infants with reset osmostat have been reported in literature are summarized below
Number in parenthesis ( ) indicate reference number. NA: Not Available, WLT: Water Loading Test, WDT: Water Deprivation Test; LT: Sodium loading test; NDI: Nephrogenic Diabetic Insipidus

In our patient, the mechanisms regulating the water excretion and retention appear to be intact. The kidney had a normal response to free water loading and water deprivation studies. The infant responded appropriately to water restriction, water loading, sodium restriction, sodium loading, and Fludrocortisone challenge, while maintaining serum sodium at a low set level. Water deprivation resulted in endogenous $\mathrm{ADH}$ release, a normal response of $\mathrm{ADH}$. Water loading produced maximally diluted urine, and the administered water was properly excreted. Meanwhile, plasma $\mathrm{ADH}$ increased with water deprivation and fell back during water diuresis. After an infusion of hypertonic saline solution, the osmoreceptors responded appropriately by enhancing excretion of $\mathrm{ADH}$, increasing urine osmolality and maintaining serum osmolality at a low set level.

The long-term outcome of infants born with reset osmostat is unknown. Our patient continues to have failure to thrive. At 24 months of age, his height and weight were still below 5th percentile. He had a normal neurological exam and had no history of seizures. The administration of high sodium supplement $(\sim 15 \mathrm{mEq} / \mathrm{kg} /$ day $)$ was able to maintain serum sodium in the range of $130-133 \mathrm{mEq} / \mathrm{L}$ (Normal 135-150 mEq/L).

In conclusion, a six-month-old infant who presented a failure to thrive and persistent hyponatremia with normal endocrine, gastrointestinal, and neurological studies meets criteria for reset osmostat. To our knowledge, this is the only infant who has congenital reset osmostat with no associated underlying malformation or systemic disease.

\section{References}

1. Robertson GL, Aycinena P, Zerbe RL (1982) Neurogenic disorders of osmoregulation. Am J Med 72: 339-353.

2. DeFronzo RA, Goldberg M, Agus ZS (1976) Normal diluting capacity in hyponatremic patients. Reset osmostat or a variant of the syndrome of inappropriate antidiuretic hormone secretion. Ann Intern Med 84: 538-542.

3. Haycock GB (1993) The influence of sodium on growth in infancy. Pediatr Nephrol 7: 871-875.

4. O'Neil M, Teitelbaum DH, Harris MB (2014) Total body sodium depletion and poor weight gain in children and young adults with an ileostomy: a case series. Nutr Clin Pract 29: 397-401.

5. Rai A, Whaley-Connell A, McFarlane S, Sowers JR (2006) Hyponatremia, arginine vasopressin dysregulation, and vasopressin receptor antagonism. Am J Nephrol 26: 579-589.

6. Rose BD, Post TW (2001) Clinical Physiology of Acid-Base and Electrolyte Disorders (5th edn) McGraw-Hill, New York, pp. 707-711.

7. Feldman BJ, Rosenthal SM, Vargas GA, Fenwick RG, Huang EA, et al. (2005) Nephrogenic syndrome of inappropriate antidiuresis. N Engl J Med 352: 1884-1890.

8. Lipschutz JH, Arieff AI (1994) Reset osmostat in a healthy patient. Ann Intern Med 120: 574-576.

9. Milionis HJ, Liamis GL, Elisaf MS (2002) The hyponatremic patient: a systematic approach to laboratory diagnosis. CMAJ 166: 1056-1062.

10. Hill AR, Uribarri J, Mann J, Berl T (1990) Altered water metabolism in tuberculosis: role of vasopressin. Am J Med 88: 357-364.

11. Bannister P, Sheridan P, Penney MD (1984) Chronic reset osmoreceptor response, agenesis of the corpus callosum, and hypothalamic cyst. J Pediatr 104: 97-99. 
12. Elisaf MS, Konstantinides A, Siamopoulos KC (1996) Chronic hyponatremia due to reset osmostat in a patient with colon cancer. Am J Nephrol 16: 349-351.

13. Howe JG, Penney MD, Currie S, Morgan D (1983) Thirst, resetting of the osmostat, and water intoxication following encephalitis. Ann Neurol 13: 201-204.

14. Kahn T (2003) Reset osmostat and salt and water retention in the course of severe hyponatremia. Medicine (Baltimore) 82: 170-176.

15. Leggott J, Almond D (2001) Reset osmostat in a 47-year-old woman with cerebral palsy. J Am Board Fam Pract 14: 317-319.
16. Assadi FK, Agrawal R, Jocher C, John EG, Rosenthal IM (1986) Hyponatremia secondary to reset osmostat. J Pediatr 108: 262-264.

17. Thiagarajan R, La Gamma E, Dey S, Blethen S, Wilson TA (1996) Hyponatremia caused by a reset osmostat in a neonate with cleft lip and palate and panhypopituitarism. J Pediatr 128: 561-563.

18. Gupta P, Mick G, Fong CT, Jospe N, McCormick K (2000) Hyponatremia secondary to reset osmostat in a child with a central nervous system midline defect and a chromosomal abnormality. J Pediatr Endocrinol Metab 13: 1637-1641. 